\title{
África em língua portuguesa: variação no português africano e expressões literárias
}

\author{
Alexandre António Timbane \\ Academia de Ciências Policiais - Moçambique \\ Universidade Federal de Goiás- Brasil
}

Sabrina Rodrigues Garcia Balsalobre

Universidade Estadual Paulista Júlio de Mesquita Filho - Brasil

Vivemos num mundo globalizado, cheio de inovações em todas as esferas da sociedade desafiando, assim, a interdisciplinaridade no espaço acadêmico-científico. Neste volume coloca-se em debate a variação linguística do português (4 capítulos) e a literatura palopiana (6 capítulos) que se entrosam ecriando um diálogo harmonioso. Assim sendo, observa-se que a língua portuguesa falada em África se distancia, paulatinamente da variedade europeia e apresenta características linguísticas próprias em nível fonético-fonológico, sintático, semântico, lexical e pragmático. A literatura 'palopiana' adquire cada vez mais identidade própria, fazendo surgir uma literatura genuinamente africana com características próprias. Essa tendência é comprovada através de vários estudos que serão aqui representados.

O espaço dos Países Africanos de Língua Oficial Portuguesa (PALOP) é multilíngue e multicultural. Essa multiculturalidade influencia de certa forma na maneira como os africanos falam ou (re)contam as suas realidades. Nenhum africano nascido e crescido naquele contexto consegue se expressar tal como se fala em Portugal, o que significa que os PALOP adotaram o português e fazem o uso segundo as realidades locais. O sistema educacional tem enfrentado insucesso devido à cópia de modelos de ensino estrangeiros e sem repensar a realidade local. Constata-se que a situação educacional nos PALOP é complexa e, por isso, algumas vozes (como as que leremos nesta obra) têm apostado na educação bilíngue como medida possível para eliminar o abandono escolar, aumentar a autoestima dos alunos e das comunidades onde as diversas línguas autóctones são faladas. Nesse sentido, esta obra reúne trabalhos de pesquisadores que discutem fundamentalmente questões internas e externas às línguas africanas; a situação do português 
em África e sua variação; e, ainda, debates sobre a literatura e seus significados no espaço dos PALOP sob perspectiva analítica de africanos e brasileiros.

Assim sendo, a primeira parte $A$ variação e a mudança do português africano oferece 5 textos. O primeiro, de Alexandre António Timbane discute $A$ variação linguística no português moçambicano: uma análise sociolinguística da variedade em uso. O texto descreve a influência do plurilinguismo na formação do português em Moçambique. Discute a relevância da política linguística colonial na formação da variedade moçambicana, assim como a influência das Línguas Bantu moçambicanas. O texto explica a razão pela qual não surgiram crioulos em Moçambique e define o conceito de moçambicanismos e sua relação com a formação da variedade. O texto termina mostrando que o português de Moçambique é uma realidade presente e cabe a cada linguista contribuir para a sua descrição bem, como para a criação de gramáticas e de dicionários que refletem a realidade moçambicana.

O segundo texto, de Ezequiel Pedro José Bernardo, é intitulado Norma e variação linguística: implicações no ensino da língua portuguesa em Angola. $\mathrm{O}$ texto descreve a diversidade linguística angolana oriunda do multilinguismo, da coabitação de cerca de vinte línguas africanas com o português, língua oficial de Angola. Este espaço sociolinguístico complexo promove o contacto linguístico e, concomitantemente, a interferência entre línguas. Situações de violências simbólicas frequentes na realidade angolana são motivadas pelo ensino que relega a variação linguística a um ensino dogmático voltado à doutrina da gramática tradicional que, ao invés de agregar as qualidades dos alunos, segrega-os. $\mathrm{O}$ texto termina aprofundando a discussão de que língua é um produto de práticas sociais, que vai sofrendo alterações em função de fatores sociais e históricos. A pesquisa chama atenção dos professores para que adotem uma pedagogia construtiva e sem preconceito.

O terceiro texto de Sabrina Rodrigues Garcia Balsalobre debate Expressões de poder e de solidariedade em Moçambique e em Angola: observando a inter-relação entre gênero e formas de tratamento. Trata-se do resultado de uma pesquisa de campo feita em Moçambique e Angola. O texto faz uma breve observação sobre as nuances particulares de uso do português em Moçambique e em Angola para depois situar o fenômeno linguístico 'formas de tratamento nominais e pronominais', à luz da Sociopragmática. Para além disso, a autora faz uma breve observação sociolinguística sobre o gênero/sexo, em função de que essa questão mostrou-se um fator motivador importante para a opção por uma forma de tratamento em detrimento de outras. Assim sendo, constatou-se a diferença no padrão de comportamento entre homens e mulheres quanto à forma de se abordar $\mathrm{o}$ interlocutor. 
O quarto texto, de Rajabo Alfredo Mugabo Abdula discute sobre $A$ criatividade da língua portuguesa: estudo de moçambicanismos no Português de Moçambique. O autor observa a preocupação em descrever a formação e a expansão lexical do português que, muitas vezes, resulta do contato entre a língua oficial e as diversas línguas bantu faladas pela maioria dos moçambicanos. A pesquisa identificou as principais línguas bantu que contribuem com formações lexicais no português moçambicano chegando à conclusão segundo a qual os estrangeirismos e os empréstimos linguísticos não 'estragam' a língua, mas sim enriquecem dão identidade à 'nossa variedade'. Concluiu-se que os empréstimos provenientes das línguas bantu para o português seguem as normas da língua de chegada e há casos de hibridismo linguístico nessas formações.

O quinto e último texto desta primeira parte é da autoria de Marcelino Horácio Velasco e de Alexandre António Timbane, cujo debate se centra no processo de ensino-aprendizagem do português no contexto multicultural moçambicano. Os autores abordam a interferência das línguas africanas na aprendizagem do português, em especial no ensino fundamental. No que se refere às experiências de práticas linguísticas no espaço escolar e as possíveis causas do fracasso escolar entre alunos provenientes de famílias pertencentes às classes multiculturais, os autores apontam a origem do problema ressaltando que não oficialização das línguas africanas nos espaços onde elas ocorrem seja um dos erros da política linguistica. Dada à complexidade que caracteriza a identidade linguística, étnica e cultural dos moçambicanos, novos desafios se impõem ao ensino fundamental, sobretudo no que se refere ao processo de formação do professor que possa receber e atuar diante de alunos provenientes de culturas distintas. $O$ texto propõe a inclusão da educação bilíngue defendendo que o bilinguismo não deve constituir problema, havendo necessidade de valorizar a relação tripartida entre língua, cultura e ensino em contexto multicultural.

A segunda parte é intitulada A literatura africana de expressão portuguesa. Nela se apresenta seis textos. O primeiro é dos angolanos, Manuel da Silva Domingos e Nsimba José cujo título é Memória coletiva e construção de identidade linguística nas narrativas de Alfredo Troni e Uanhenga Xitu. O estudo analisa as narrativas de Uanhenga Xitu e Afredo Troni sob a perspectiva discursiva e da memória coletiva. Considerando a textualidade, os autores demonstram que, apesar da variação estilística e linguística, os textos dessas narrativas obedecem aos critérios de textualidade típicas do português, sobretudo no que diz respeito à coesão gramatical e à coerência. Contudo, há também estruturas consideradas formalmente agramaticais, denunciando a presença da variação no português angolano. $\mathrm{O}$ texto conclui que as duas narrativas contribuem muito para a construção da 
identidade linguística do Português de Angola, recorrendo aos dados da memória coletiva, que permitem reportar práticas linguísticas típicas das comunidades representadas nas narrativas.

O segundo texto, O luso, o trópico e o cão tinhoso nas revelações literárias de Honwana, é da autoria de Sueli Saraiva e faz reflexões sobre a resistência intelectual às ideias lusotropicalistas dos movimentos anticoloniais em Moçambique, e também em outros territórios colonizados. $\mathrm{O}$ texto analisa o texto do moçambicano Luís Bernardo Honwana, analisando as reivindicações pela autodeterminação dos povos africanos e de libertação total das amarras do velho império, buscando o lastro na teoria freyreana. Ao se oporem à calamitosa subjugação social, econômica, cultural e política que organizava a dinâmica da sociedade colonial, favorecendo exclusivamente um pequeno grupo dominante, os agentes da mudança, usando armas concretas e simbólicas, desmascararam o discurso fundado numa fantasia político-ideológica e numa cegueira voluntária, devidamente apropriada pelo Estado português. O que prevaleceu na história testemunhada pela ficção do imortal Nós matamos o cão tinhoso foi a desconstrução de um mito e a demonstração da prevalência do "inferno de exploração, segregação e violência", marcas indeléveis de quaisquer regimes de dominação.

O terceiro texto, da autoria de Maurício Silva tem como título Os sentidos e os não sentidos da língua portuguesa: questões de língua e linguagem nos contos de Mia Couto. Nele se analisa o processo de colonização apontando para a imposição ao colonizado um outro modo de falar que atuou no sentido de sequestrar ao colonizado a possibilidade e o direito de narrar, de contar histórias. $\mathrm{O}$ texto analisa o português transplantado, no contexto da colonização, mostrando a sua artificialidade e a função de instrumento de exclusão ao invés de servir de instrumento de ingresso no mundo dos direitos. De acordo com o autor, Mia Couto - um dos principais expoentes da literatura africana - desfaz essa distorção por meio de um 'idioma' que, efetivamente, resgata não apenas o modo de falar do homem moçambicano, mas principalmente seu modo de ser: sua cultura, sua personalidade, sua religião. Torna, assim, o seu 'rabisco fora da cartilha' num riscado dentro da existência.

O quarto texto, A mulher nos contos de Mia Couto: uma leitura pós-colonial, foi elaborado por Márcia Moreira Pereira e retoma discussões autor do texto anterior, mas focando para perspectiva feminista. A autora analisa o quanto a voz feminina torna-se, por meio dos artifícios literários, forte e consistente, apesar de tanta opressão, mas também o quanto ainda falta para que se afirme plenamente como uma voz da liberdade. Na escrita miacoutiana, as protagonistas são mulheres presas à cultura patriarcal, às amarras do colonialismo e a seus 
próprios medos. Nos dois contos analisados, as personagens discutem sua condição feminina e o seu desenraizamento: uma é abandonada e assume sua condição de mulher livre; outra abandona, mas não consegue se libertar das amarras morais presentes em sua vida durante tanto tempo, recusando, assim, sua própria liberdade, por não saber o que fazer com ela. $\mathrm{O}$ texto termina apontando duas angústias: a da libertação colonial ou matrimonial e da conscientização, por meio da qual se mostra possível alcançar a liberdade, embora com dificuldades em aceitá-la. A mulher representada nos contos miacoutianas pode ser compreendida não apenas como figura submissa e incapaz, mas como sujeito de sua própria história, que, ao tomar consciência de sua condição pessoal e social, finalmente, liberta-se.

$\mathrm{O}$ quinto texto, $O$ silêncio anticolonial de Conrad e Eça, ou a impossível arte de narrar o horror, de José Carlos Siqueira, analisa duas obras em que a história a ser contada não está lá - tudo o que a narrativa concreta faz de significativo é um gesto, uma indicação para um (não-)signo, um (não-)texto, uma outra (não-) obra, que existe na sombra da obra concreta. Em $O$ coração das trevas, os vários narradores gesticulam com seu contar para outras narrativas, as quais quanto mais se distanciam da narrativa originária, mas perto se aproximam do inumano, ou da irrealidade do humano. Em A ilustre Casa de Ramires, cada "autor" gesticula com seu livro para outros livros, cujo limite é o romance que não pode se escrito, mas que habita à sombra do romance concreto. $\mathrm{O}$ texto fecha as análises mostrando que o inapreensível se situar nessas obras dentro do campo psicanalista do Tânatos, mas não em sua fenomenologia individual e sim no seu caráter específico, relativo à espécie humana. Indica-se no gesto dessas narrativas para o aquilo que há de mais destrutivo e incontrolável no caráter humano, na pulsão de morte que move não apenas o espécime mais toda a espécie. Algo que como a Medusa, destrói ao ser olhado e, por isso, precisa do escudo de Teseu para ser refletido, mas não apreendido.

O último texto, $O$ uso das 'Languages of Wider Communication' na música moçambicana, de Cremildo G. Bahule, trata da interação linguística entre a música e as línguas usadas na redação das letras. A pesquisa comprova um uso forte das LWC na música moçambicana, entendendo que os artistas fazem uso da língua como mercadoria e isso provoca uma batalha linguística que caminha de forma paralela com a batalha musical. O texto mostra que o uso das LWC como o inglês, o francês e o português faz com que os músicos usem a língua em conexão com a música, e a arrostem como uma mercadoria. Esta visão artística revela uma 'batalha das línguas' (Lopes, 2004) entre as LWC e as línguas autóctones ou no seio das LWC, o que se torna uma força motriz para que se desenvolva uma batalha das músicas. Retoma-se a necessidade da preservação e revitalização dos 
patrimônios culturais do país. Porém, mais do que fomentar batalhas (linguísticas e musicais), deve-se articular essas duas realidades com a finalidade de alavancar a música moçambicana e inseri-la de modo sazonado, no mundo globalizado.

Sabe-se da dificuldade que esses países enfrentam na produção de materiais que discorrem acerca de sua situação linguística e literária. Dessa forma, essa obra traz uma contribuição para que a democratização do conhecimento seja mais ampla no esoaço lusófono. Por isso, propõe-se a divulgação desse livro por meio físico e eletrônico, a fim de que a sua circulação seja maior e mais democrática, podendo atingir um público mais amplo e distante geograficamente. 